tried to point out in this letter, structural differences between manmade mineral fibres and chrysotile asbestos and the resulting biological evidence do not lead to the conclusion of comparable toxicity. In addition Bellman et al have added important knowledge regarding the considerable differences between fibre types in respect of their persistence in rat lungs: calculated half times of manmade mineral fibres in animal lungs were relatively short (for glass and rock wool about 280 days). After intratracheal instillation of the same concentrations of chrysotile fibres, the number of fibres longer than $5 \mu \mathrm{m}$ increased continuously over two years to about 15-fold due to splitting in elementary fibrils. ${ }^{5}$ It is difficult to understand why this conflicting evidence should lead to similar threshold limit values for chrysotile and manmade mineral fibres because this would mean that much higher effective concentrations of chrysotile are accepted in human lungs.

JAN M M MEIJERS

Department of Occupational and Environmental Health and Toxicology,

University of Maastricht, PO Box 616, 6200 MD Maastricht,

The Netherlands

1 Scholze $\mathrm{H}$, Conradt R. An in vitro study of the chemical durability of siliceous fibres. Ann Occup Hyg 1987;31:68392.

2 Leineweber JP. Solubility of fibres in vitro and vivo. In: Biological effects of man-made mineral fibres. Proceedings of a WHO/IARC conference, Copenhagen, 1982. Copenhagen: World Health Organisation, 1984;2:87-101.

3 International Agency of Research on Cancer. IARC monographs on the evaluation of carcinogenic risks to humans. Vol 43. Man-made mineral fibres and radon. Lyon: IARC, 1988.

4 Cherrie JW, Crawford NP, Dodgson J. Problems in assessing man-made mineral fibre concentrations in relation to epidemiology. Ann Occup Hyg 1988;32:715-23.

5 Bellmann B, Muhle H, Pott F, König H, Klöppel H, Spurny K. Persistence of man-made mineral fibres (MMMF) and asbestos in rat lungs. Ann Occup Hyg 1987;31:693-709.

\section{Author's reply:}

I am pleased that Meijers agrees that "...it is absolutely necessary in the research concerning mineral fibres to depend on fibre counts instead of gravimetric data." This was, after all, the main message of the editorial and I should like to add that it applies not only to mineral fibres but to all res- pirable fibrous materials, natural and synthetic, inorganic and organic.

Meijers' disagreement centres mainly on my "implicit statement that some manmade mineral fibres are at least as dangerous as chrysotile..." and that "...it follows that this must lead to the same threshold limit values for chrysotile and manmade mineral fibres" (sic).

Firstly, I hasten to emphasise that any statement to the effect that some respirable fibrous materials are as potent (or less, or more, or equally potent) as chrysotile must be qualified by adding "...on a fibre for fibre basis." To illustrate this qualification, I suggest an examination of the data from Kevlar (pulp) inhalation studies in the rat, recently published by the International Labour Office which indicates that fibrosis was seen in animals dusted for two weeks with 18 $\mathrm{mg} / \mathrm{m}^{3}$, and that in rats exposed chronically ( 24 months) to 100 and $400 \mathrm{f} / \mathrm{ml}$ doses squamous cell tumours were found, and that dose dependent fibrosis was found in rats exposed to 25,100 , and $400 \mathrm{f} / \mathrm{ml}$ but no adverse effects were found at the $2.5 \mathrm{f} / \mathrm{ml}$ exposure level (ILO meeting of experts on safety in the use of mineral and synthetic fibres, Geneva, 1989. (Working document.))

In the first study the authors indicate that a dust cloud of $18 \mathrm{mg} / \mathrm{m}^{3}$ corresponds to $2000 \mathrm{f} / \mathrm{ml}$. Compare this with the number of fibres $(L \geqslant 5$ $\mu \mathrm{m}, \mathrm{D} \leqslant 0 \cdot 1 \mu \mathrm{m})$ that have been counted in $1 \mathrm{mg}$ of UICC chrysotile: $13300 \times 10^{6}$. If one were to disperse $18 \mathrm{mg}$ of UICC chrysotile fibres in one cubic metre some $239400 \mathrm{f} / \mathrm{ml}$ of chrysotile would be found. On the other hand, if $239400 \mathrm{f} / \mathrm{ml}$ (chrysotile) is equivalent to $18 \mathrm{mg} / \mathrm{m}^{3}$ then $100 \mathrm{f} /$ $\mathrm{ml}$ would correspond to $0.007 \mathrm{mg} / \mathrm{m}^{3}$.

On the basis of these numbers, I submit that if Kevlar (pulp) fibres, at exposure levels of 100 and $400 \mathrm{f} / \mathrm{ml}$ that is, $0.9 \mathrm{mg} / \mathrm{m}^{3}$ and $3.6 \mathrm{mg} / \mathrm{m}^{3}$ produce fibrosis and tumours it would be surprising if exposure to 100 and $400 \mathrm{f} / \mathrm{ml}$ of chrysotile $(0.007$ and 0.028 $\mathrm{mg} / \mathrm{m}^{3}$ ) produced similar effects. This example illustrates the importance of comparing biological effects of all respirable fibrous materials not only on a gravimetric basis but more appropriately on the basis of fibre number.

With respect to manmade mineral fibres, specifically glass fibres (including special purpose fibres) or rock wool in inhalation studies conducted to data, the ILO working document referred to above states: "In several of the relevant studies, an increase in lung tumours that was not statistically significant was found in exposed animals. In all of the carcinogenicity bioassays conducted to date similar mass concentrations of chrysotile asbestos have clearly induced lung tumours, whereas crocidolite asbestos has induced few or no tumours. However, available data are insufficient to draw conclusions concerning the relative potency of various fibre types, because the true exposure (number of respirable fibres) was not characterised in most of these studies" (page 11, emphasis added).

I agree with Meijers that durability is of paramount importance in determining long term potency. This appears to be the key factor separating chrysotile asbestos from the amphiboles, the latter persisting (and thus accumulating with repeated exposures) for a whole lifespan. But it seems that the final word on the relative in vivo solubilities of different fibres has not yet been said. Indeed, the ILO working document indicates: "The solubility of man-made mineral fibres in vitro and their durability in vivo vary with chemical composition. While, in general, glasswool fibres appear to be relatively non-durable, one sample (editor's note: fibres of alkali free borosilicate glass) was shown to be very insoluble in vitro. Conversely, while in one study ceramic fibres were very durable, one sample proved to be as soluble as glasswool used for comparison in the same experiment in vitro. Insufficient samples of slagwool and rockwool have been tested to allow a prediction of their overall range of solubility in tissues. On the available evidence, no generalisation can be made regarding the durability of any single class of manmade mineral fibres" (page 12, emphasis added).

I would submit that this whole issue should not be regarded as a matter of controversy but rather as a subject of future well designed experimental research investigations.

1 Palekar LD, Most BM, Coffin DL. Significance of mass and number of fibers in the correlation of V79 cytotoxicity with tumorigenic potential of mineral fibers. Environ Res 1988;46:142-52. 